\title{
PHYTONYMIC SYMBOLISM IN BULGARIAN AND RUSSIAN FOLK ART
}

\author{
Stefka Petrova', Marian Petrov²
}

\section{stefi38@abv.bg; aspabg@abv.bg}

'Sofia University "St. Kliment Ohridski", Sofia, Bulgaria 2Interpreter, Independent Researcher, Sofia, Bulgaria

\begin{abstract}
The report examines the anthropologized and other semantic and connotative loads of the names of some plants (wormwood and oregano) in Bulgarian and Russian folk art. The topic is related to the comparative study of a cultural heritage of the two nations. In recent years, linguistics in the Bulgarian and Russian languages has increased research in this direction. An example of developments in both languages is the recent research by Anna Angelova.
\end{abstract} Russian

Keywords: Folk Art; Phytonymic Symbolism; Linguistics; Bulgarian;

\section{ФИТОНИМИЧНА СИМВОАИКА В БЪАГАРСКОТО И РУСКОТО НАРОАНО ТВОРЧЕСТВО}

\author{
Стефока Петрова', Мариян Петров² \\ 'Софрийски университет „Св. КАимент Охрилски“, Софрия, България \\ 2Преволач, Софрия, Бьлгария
}

\begin{abstract}
Резюме: АоклаАьт разглежАа антропологизираните и Аруги семантични и конотативни натоварвания на наименованията на някои растения (пелин и риган) в българското и руското народно творчество. Темата е свързана със сравнително изследване на културно-историческото наслеАство на Авата народа. През послеАните гоАини в мингвистиката на българския и руския език зачестяват научните изследвания в тази посока. Пример за разработките на Авата езика са последните изследвания на Анна Ангелова.
\end{abstract}

КАючови Ауми: нароАно творчество; фоитонимична символика; езикознание; български език; руски език

В народното творчество, независимо на какъв език е създалено, постоянно се среща антропологизиране и Аруги семантични и конотативни натоварвания на различни растения. Това е така, защото растенията, като част от живата прирола, играят голяма роля в живота на човека. От елна страна, те осигуряват живота му чрез фотосинтезата, от 
Аруга - създават красота чрез зеленината, цветовете и п^одовете, от трета служат за храна (или полправка на храната), имат приложение в медицината и пр., и пр.

Затова ги срещаме възпети в народните песни и приказки. Това е част от приказното, от художествения поглеА на народния творчески гений вьрху заобикалящата го срела. И както е характерно за народните говори, това засяга не само официалното название на растението, но и диалектните му варианти. Макар и много по-рялко срещано, отколкото при представителите на животинския свят, антропологизирането на растенията се изразява най-често с възможността им за вербална комуникация с Аруги представители на фрлората и с фрауната, най-вече - с хората. Т.е. като живи същества те разговарят както с хората, които имат вербален език, така и помежлу си, в приказния свят. Много и разнообразни са растенията, за които се пее и разказва в приказното творчество на всички народи. Аа посочим за пример здравеца, босилека, трендафила, яголата, малината, и Аървесните ябълка, череша и Ар.

\begin{tabular}{|c|c|}
\hline В БЪАГАРСКОТО НАРОАНО ТВОРЧЕСТВО: & В РУСКОТО НАРОАНО ТВОРЧЕСТВО: \\
\hline 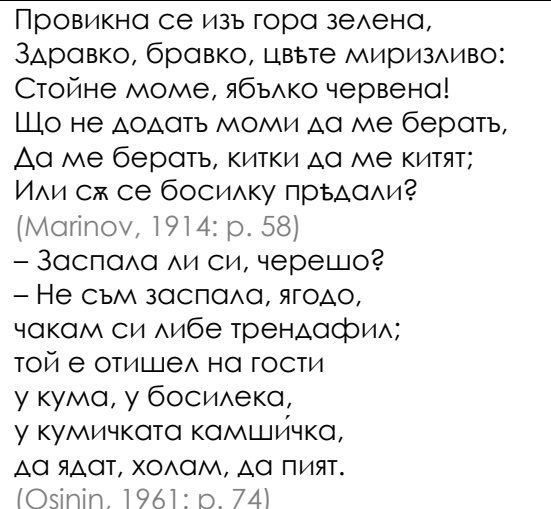 & 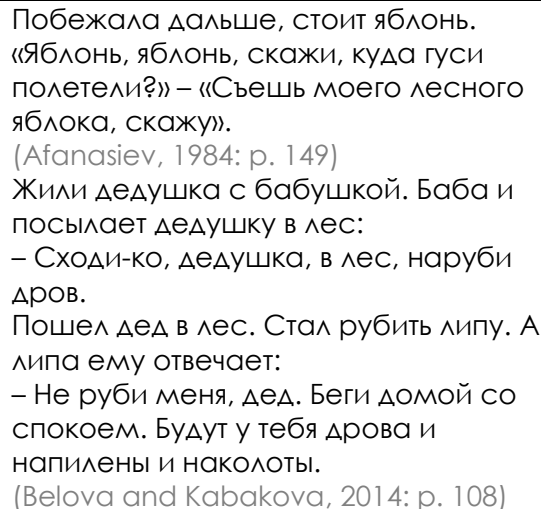 \\
\hline
\end{tabular}

ТАБАИЦА 1.

Най-често в народното творчество фоитонимите са свьрзани с представите на хората за съответните растения. Така например пелинът е растение, олицетворяващо горчивина и печал, което намира отражение в устното народно творчество. Така, изразявайки отношението си към нещо неприятно, предизвикващо болка, обила, огорчение, а също така - вълнение, безпокойство, това растение се споменава в иАиоми, в пословици в руския и българския език (Angelova, 2016: p. 22). 


\begin{tabular}{|c|c|}
\hline В БЪАГАРСКОТО НАРОАНО ТВОРЧЕСТВО: & В РУСКОТО НАРОАНО ТВОРЧЕСТВО: \\
\hline $\begin{array}{l}\text { Зять като мель, сынь като пелынь. } \\
\text { (Gerov, 1977: р. 22) } \\
\text { Чер като катран, кисел като оцет, } \\
\text { горчив като пелин. } \\
\text { (Stranski, 1963: p. 19) }\end{array}$ & $\begin{array}{l}\text { Не ^юбовь, а полынь. } \\
\text { (Kusznetsov, 2001: р. 571) } \\
\text { Батькова хлеба не хочеться; } \\
\text { Батькив хлеб полынем пахне. } \\
\text { (Kostomarov, 1843: р. 39) }\end{array}$ \\
\hline
\end{tabular}

\section{ТАБАИЦА 2.}

В същата статия Г. Ангелова дава полобни примери и в българските народни песни (Angelova, 2016: р. 22), но такива се срещат И в руското народно песенно творчество:

\begin{tabular}{|c|c|}
\hline В БЪАГАРСКОТО НАРОАНО ТВОРЧЕСТВО: & В PУСКОТО НАРОАНО ТВОРЧЕСТВО: \\
\hline $\begin{array}{l}\text { Момиче, голем гяволо, не холи ситно } \\
\text { преА мене, не залавай ми ялове, } \\
\text { ядове, мибе, пелини. Ботевградско } \\
\text { [Сб. за нар. умотв., XXXVIII, 1910]" } \\
\text { (Stranski, 1963: р. 19) }\end{array}$ & $\begin{array}{l}\text { Ах, чужая-то жена - ^ебель белая моя; } \\
\text { КогАа обок-то силит, как огнем она } \\
\text { палит... } \\
\text { А своя-то жена - полынь горькая трава: } \\
\text { Она обок-то силит, как морозом } \\
\text { ознобит... } \\
\text { (Sobolevsky, } 1895-1899 / 3: \text { р. } 366 \text { ), } \\
\text { (Shane, 1898: р. 206) }\end{array}$ \\
\hline
\end{tabular}

ТАБАИЦА 3.

Семиотизирането на фоитонимите в народното творчество не винаги е еАнозначно. „... напримьрь, калина въ Пьсняхь, взятая Сь признаками, характеризующими ея вньшній виАь, связывается вь народномь сознаніи сь картинами свьтАЫми, веселыми и, напротивь, - с печальными, если принять во вниманіе горечь ея плоАовь." (Avtamonov, 1902: 48). Макар и писано за руските народни песни, това важи в пьлна сила и за българските, и не само за фоитонима „калина“ и за цитираните признаци:

\begin{tabular}{|c|c|}
\hline В БЪАГАРСКОТО НАРОАНО ТВОРЧЕСТВО: & В РУСКОТО НАРОАНО ТВОРЧЕСТВО: \\
\hline 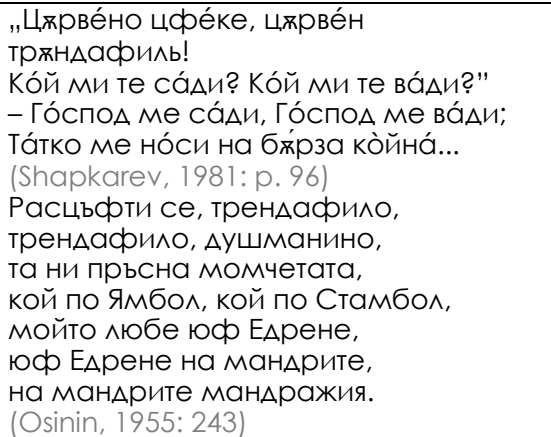 & 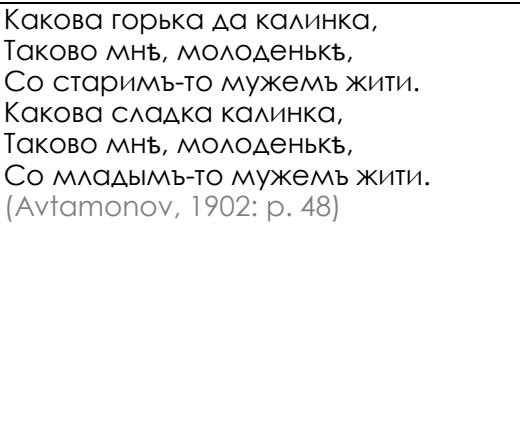 \\
\hline
\end{tabular}

ТАБАИЦА 4. 
Семантичната мотивираност на българските народни названия на растенията за съжаление е слабо застьпена в научната ни митература. Може $\Delta \mathrm{a}$ се каже, че лингвистите, етнографрите и фоолклористите у нас са в Аьлг преА тази тема, а тя е обширна и Аостойна за изслелване. Аобър опит, макар и предимно в номинацията на растенията, при това сьпоставително с руската, е номинацията на Betonica officinalis L. в руския и българския език чрез ономасиологичния полхол (Angelova, 2019: рр. 5-14), както и определянето на принципите за номинация на овошките: вишна, череша, грозАовиАна песъкиня (Angelova, 2013: рр. 71-80). Внимание заслужава и разглежлането на ономасиологичните признаци на наименованията на някои лекарствени растения (Angelova, 2018: pp. 37-45). Всичките тези заглавия, а и Аоста Аруги, не само на цитираната авторка, са Аобра основа за широкомащабни изслеАвания в тази област.

\section{Аитература / References}

Afanasiev, A. N. (1984). Folk Russian fairy tales. Vol. 1. Moscow, 1984 (In Russian) / [Афранасьев, А. Н. Народные русские сказки. Т. 1. Москва, 1984]

Angelova, A. (2013). Principles of nomination of fruit crops in Russian and Bulgarian languages. In: Jubilee Scientific Conference "50 Years - A Door to Education and a Window to the World". Sofia, 2013. (In Russian) / [Ангелова, А. Принципы номинации плодовых культур (вищни, черешни, черемухи) в русском и болгарском языках. - В: Юбилейна научна конференция „50 голини врата към образованието и прозорец към света". Софрия, 2013.]

Angelova, G. (2016). Features of nomination of medicinal plant wormwood (Artemisia absinthium L.) (on the material of Russian and Bulgarian). - In: Comparative Linguistics № 4. Sofia, 2016. (In Russian) / [Ангелова, Г. Особенности номинации лекарственного растения полынь горькая (Artemisia absinthium L.) (на материале русского и болгарского языков). - В: "Сьпоставително езикознание" № 4. Софиия, 2016.]

Angelova, A. V. (2018). Folk medicine in the names of medicinal plants (on the material of Russian and Bulgarian languages). - In: "Rusistics: Yesterday, Today, Tomorrow. Anniversary International Scientific Conference dedicated to the 50th Anniversary of the Society of Rusists of Bulgaria and the 50th Anniversary of the International Association of Teachers of Russian Language and Literature". Sofia, 2018. (In Russian) / [Ангелова, А. В. Народная медицина в наименованиях лекарственных растений (на материале русского и болгарского языков). - В: „Русистика: вчера, сегодня, завтра. Юбилейная межлународная научная конференция, посвященная 50-летию Общества русистов Болгарии и 50-летию МежАународной ассоциации преподавателей русского языка и митературы". София 2018.] 
Angelova G. (2019). Nomination of medicinal plant Betonica officinalis L. in Russian and Bulgarian languages (onomasiological approach). - In: Bulgarian Rusistics № 1. Sofia, 2019. (In Russian) / [Ангелова Г. Номинация ^екарственново растения Betonica officinalis L. в русском и болгарском языках (ономасиологический подход). - В: „Болгарская русистика“ №1. С., 2019]

Avtamonov, A. (1902). Symbolism of plants in Great Russians. In: Journal of the Ministry of People's Education. The seventh decade. Part CCCXXXXIV. St. Petersburg. 1902 (In Russian) / [Автамонов, Я. А. Символика растеній въ великорусскихъ пьсняхь. В: Журналь Министерства народнаго просвьщенія. Седьмое Аесятильтіе. Часть СCCXXXXIV. С.Петербург. 1902]

Belova, O. V.; Kabakova, G. I. (2014). At the origins of the world: Russian etiological tales and legends. Moscow, 2014. (In Russian) / [Белова, О. В., Кабакова, Г. И. У истоков мира: Русские этиологические сказки и легенды. Москва, 2014.]

Gerov, N. (1977). Dictionary of the Bulgarian language. Part Four. Sofia, 1977. (In Bulgarian) / [Геров, Н. Речник на българския език. Част четвърта. С., 1977.]

Kostomarov, N. I. (1843). On the historical significance of Russian folk poetry. Kharkov, 1843. (In Russian) / [Костомаров Н. И. Об историческом значении русской народной поэзии. Харьков, 1843.]

Kusznetsov, (ed) (2001). Modern Interpretive Dictionary of Russian. See ed. S.A. Kuznetsov Blacksmiths. St. Petersburg, 2001. (In Russian) / [Современный толковый словарь русского языка. ГА. р. С.А. Кузнецов. С.-Петербург, 2001]

Marinov, D. (1914). Compendium of Folk Creation and Folklore. Book. XXVIII. Sofia, 1914. (In Bulgarian) / [Маринов, А. Сборникъ за народни умотворения и народописъ. Кн. XXVIII. Софиия, 1914.]

Osinin, D. (1955). Tree canteen. Household folk songs. Sofia, 1955. (In Bulgarian) / [Осинин, А. Аьрво столовато. Битови народни песни. Софиия, 1955.]

Osinin, D. (1961). From a small leaflet on a stalk. Folk Songs. Sofia, 1961. (In Bulgarian) / [Осинин, А. От ^ехичка по стръкче. Народни песни. Софиия, 1961.]

Shapkarev, K. A. (1981). Collection of Bulgarian folk works. Part One. Section I. Samovil, Religious and Ritual Songs. Book I. Sofia. 1981. (In Bulgarian) / [Шапкарев, К. А. Сборникь оть болгарски народни умотворения. Часть пьрва. ОтАьль І. Самовилски, религиозни и обрялни пьСни. Книга І. София. 1981.]

Shane, P. V. (1898). Velyorus in his songs, rituals, customs, beliefs, fairy tales, legends, etc. Vol. 1. St. Petersburg 1898. (In Russian) / [Шейн П. В. Великорус в своих песнях, обрядах, обычаях, верованиях, сказках, легендах и т. п. Т. 1. Вып. 1. LVIII. Санкт Петербург 1898]

Sobolevsky, A. I. (1895). Great Russian folk songs. In 5 volumes Volume 3. St. Petersburg, 1895-1899. (In Russian) / [Соболевский, А. И. Великорусские народные песни. В 5 т. Том 3. Санкт Петербург, 1895-1899.]

Stranski, I. (1963). Wild and cultivated plants in Bulgaria. Sofia, 1963. (In Bulgarian) / [Странски, И. Аиви и културни растения в България. Софрия, 1963.] 


\section{КУАТУРНО-ИСТОРИЧЕСКО НАСАЕАСТВО: \\ ОПАЗВАНЕ, ПРЕАСТАВЯНЕ, АИГИТААИЗАЦИЯ}

CULTURAL AND

HISTORICAL

HERITAGE

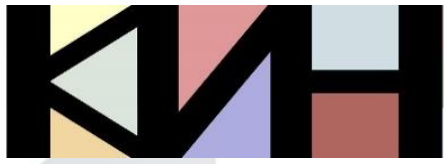

PRESERVATION PRESENTATION

DIGITIZATION
Материалите в сборника са обект на авторско право. Разрешава се безвъзмезАното ползване на техни електронни/ хартиени копия само за лична употреба или обучение, при пь^но цитиране на текущата страница и слеА писмена декларация от цитиращия за Аипса на търговски намерения. За копиране пол Аруга фрорма, препубликуване или публикуване на сървъри се изисква писмено разрешение и/или заплащане.

() Авторски колектив, 2019 Технически реАактори: Николай Ноев Калина Сотирова-Вълкова Ка^оян Николов

\section{Editors}

Galina Bogdanova Vanya Mateeva

This work is subject to copyright. Open and free of charge use of digital/hard copies of publications is granted only for personal or educational use, with full citation of the current page, and after written declaration of the quoting side for not-commercial Intention. For any other reproducing types, republishing, photocopying, recording, or any other storage retrieval system/ server written permission and/or fee is required.

(C) Authors` Group, 2019

Technical editors:

Nikolay Noev

Kalina Sotirova-Valkova

Kaloyan Nikolov

Научна поредица: том 5, брой 2 (7)/2019

Science series: vol. 5 , issue $2(7) / 2019$

www.math.bas.bg/vt/kin

ISSN: 2367-8038 